\title{
Strengthening of RC plates with mineral-bonded composite layers for enhanced impact safety
}

\author{
Marcus Hering ${ }^{1, *}$, and Manfred Curbach $^{1}$ \\ ${ }^{1}$ Technische Universität Dresden, Faculty of Civil Engineering, Institute of Concrete Structures, 01062 \\ Dresden, Germany
}

\begin{abstract}
The presented paper deals with a series of impact experiments conducted in the drop tower facility of the Otto Mohr Laboratory (OML) at the Technische Universität Dresden. The presented research results were generated in three projects. A number of reinforced concrete (RC) plates which were subsequently strengthened on the not-impacted side were produced and tested. As basic materials for the RC plates, a normal strength concrete $(\mathrm{C} 35 / 45)$ and conventional BSt500 reinforcement steel were used. Different material combinations, cement-bonded composites were chosen for the subsequently applied strengthening layer. The paper presents the experimental program, the used test facility, and the results of the experiments and their interpretation.
\end{abstract}

\section{Introduction and state of the art}

The investigation of the effect of impact loads on components or structures made of reinforced concrete (RC) has been a relevant aspect of scientific studies for many years. This knowledge is especially relevant for designing RC structures to withstand impact loads, see e.g. [[1], [2]]. In order to improve the analytical design and simulation methods available for the description of RC components exposed to impact loads, national and international investigations have been carried out for many years as well, see [[3], [4], [5]].

For some time, the design or subsequent calculation of the resistance of RC components against an impact load is no longer the only topic of interest. The research focus has shifted towards the strengthening of existing structures especially for the scenario of impact loads. There are different approaches to achieve this. On the one hand, damping layers were considered on the impact-facing side of the structure, see [[6]]. This is particularly interesting for the construction of rockfall galleries. On the other hand, thin strengthening layers - often using alternative reinforcement materials based on continuous fibres - on the opposite side of the impact event can be used to make components more resistant, see e.g. [[7], [8]].

The fact that such thin reinforcing layers work very well under static loads has been shown by many researchers like [[9]-[14]]. In the following, a study concerning the use of such layers for the strengthening of RC components against impact stress will be presented. For this purpose, a selection of different possible strengthening materials was subsequently

\footnotetext{
* Corresponding author: Marcus.Hering@tu-dresden.de
} 
applied to prepared RC plates and subjected to an impact load. The resulting data will be presented in the following sections.

\section{Specimen and experimental setup}

\subsection{Production and preparation of the test samples}

Samples with a basic geometry of $1.5 \mathrm{~m} \times 1.5 \mathrm{~m} \times 0.3 \mathrm{~m}$ were examined. For the first part of the investigations - a study on unstrengthened $\mathrm{RC}$ plates under different fast impact events [[15]] -, five conventional RC plates were produced. A concrete quality of C35/45 with a maximum grain size of $8 \mathrm{~mm}$ was used for the production of these plates. Steel bars (BSt500 according to DIN 488-1 [[16]]) with a diameter of $8 \mathrm{~mm}$ and a spacing of $100 \mathrm{~mm}$ were crosswise arranged as upper and lower reinforcement layers. The intended concrete cover for the test specimens was $25 \mathrm{~mm}$, see [[15]].

Generally, concrete surfaces are sandblasted to achieve the required roughness before a reinforcing layer is applied. Here, another variant was tested. Therefore, additional four RC plates were prepared during production in such a way that a washed concrete surface was created on the bottom side of the plates. For this purpose, retarder paper was placed in the formwork before concreting. With the help of this retarder paper it was possible to roughen the surface by blasting with water. The concrete surface was prepared in order to achieve a good bond between the strengthening layer and the plate to be strengthened via the surface roughness. In Fig. 1 you can see a rough surface. Before strengthening, the relevant surface was moistened, starting 24 hours before the strengthening works.

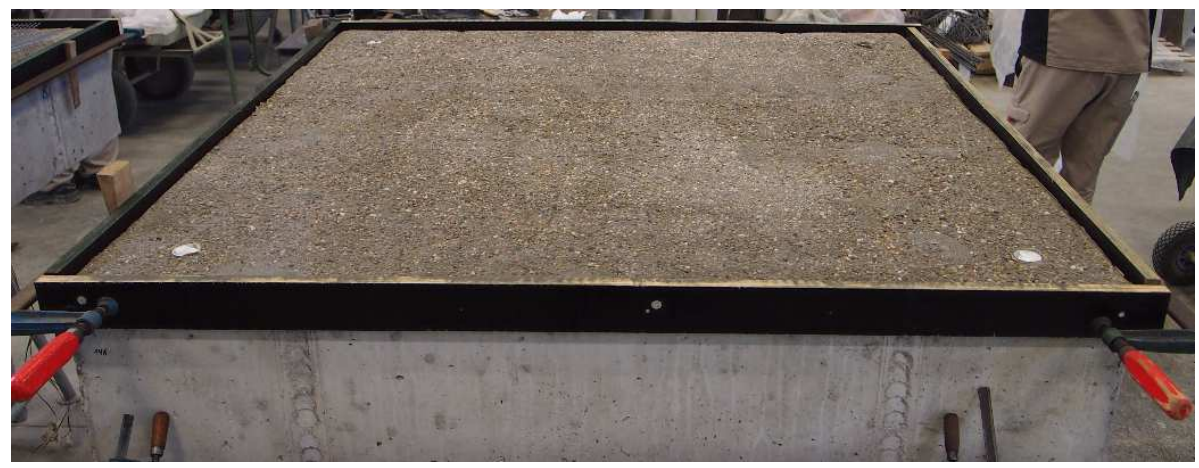

Fig. 1. Plate prepared for strengthening, picture: M. Hering.

Different materials were used for the strengthening layer, see Table 1 and Table 2

Table 2The thickness of these layers was $20 \mathrm{~mm}$. When strengthening the component, first of all, approx. $7 \mathrm{~mm}$ Pagel TF10 [[17]] fine concrete was applied. The first sheet of reinforcing material was inserted into this layer. A further layer of matrix material (approx. $6 \mathrm{~mm}$ thick) was then applied, followed by the second layer of the reinforcement material. The work was completed with a final layer of approx. $7 \mathrm{~mm}$ fine concrete Pagel TF10. Fig. 2 shows the process of applying the strengthening.

Plate no. PL147 is an exception here. Only $2 \mathrm{~cm}$ of fine concrete (without reinforcement) were applied to this test specimen to assess the effect of the additional plate thickness. After the completion of the strengthening work, the fresh concrete surface was covered with moist towels. These were removed after 7 days. The further storage of the test specimens took place in the yard of the Otto Mohr Laboratory (OML). The experiments were conducted 28 days after the application of the strengthening layer. The bending tensile strength of the fine 
concrete at this time was $5.7 \mathrm{~N} / \mathrm{mm}^{2}$, the cube-compressive strength was $91.0 \mathrm{~N} / \mathrm{mm}^{2}$. Furthermore, a density of $2.19 \mathrm{~g} / \mathrm{cm}^{3}$ was measured.

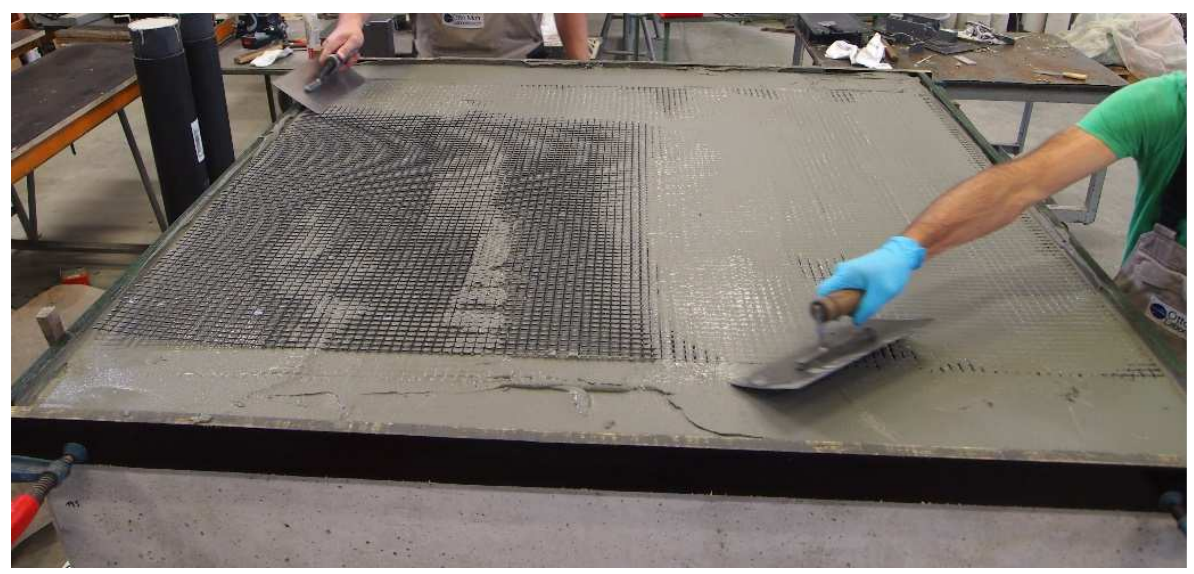

Fig. 2. Application of the strengthening layer, picture: M. Hering.

Table 1. Applied strengthening materials and experimental parameters.

\begin{tabular}{|c|c|c|c|}
\hline Specimen label & Matrix material & Reinforcing material & Experimental parameter $\left.{ }^{*}\right)$ \\
\hline PL140-144 & \multicolumn{2}{|c|}{ Not strengthened } & $\mathrm{L}_{\mathrm{Imp}}=380 \mathrm{~mm}$ \\
\hline PL145 & \multirow{4}{*}{ Fine concrete } & Carbon fabric 1 & $\mathrm{~d}_{\mathrm{Imp}}=100 \mathrm{~mm}$ \\
\hline PL147 & & None & $m_{\text {Imp }}=21.66 \mathrm{~kg}$ \\
\hline PL148 & & Glass fabric & VImp,unstrengthened $=44 \ldots 74 \mathrm{~m} / \mathrm{s}$ \\
\hline PL149 & & Carbon fabric 2 & VImp, strengthened $=$ approx. $68 \mathrm{~m} / \mathrm{s}$ \\
\hline
\end{tabular}

${ }^{*}$ symbols are explained in the next section

Table 2. Characterization of the fabrics applied as the strengthening layers; data taken from [[8]].

\begin{tabular}{|c|c|c|}
\hline & \multicolumn{2}{|c|}{ Characteristics } \\
\hline \multirow{4}{*}{ Carbon fabric 1 } & Material & Carbon \\
\cline { 2 - 3 } & Binding type & Warp knitting \\
\cline { 2 - 3 } & Linear density weft $\mid$ warp & 800 tex $\mid 3450 \mathrm{tex}$ \\
\cline { 2 - 3 } Carbon fabric 2 & Mesh size & $14 \mathrm{~mm} \times 11 \mathrm{~mm}$ \\
\cline { 2 - 3 } & Material & Carbon \\
\cline { 2 - 3 } & Binding type & Warp knitting \\
\cline { 2 - 3 } AR glass fabric & Linear density & $16 \mathrm{~mm} \times 13 \mathrm{~mm}$ \\
\cline { 2 - 3 } & Mesh size & Glass \\
\cline { 2 - 3 } & Material & Leno weave \\
\cline { 2 - 3 } & Binding type & 320 tex $\mid 320$ tex \\
\cline { 2 - 3 } & Linear density & $4 \mathrm{~mm} \times 5 \mathrm{~mm}$ \\
\hline
\end{tabular}

\subsection{Experimental setup}

The accelerated mode of the drop tower facility available at the OML was used for the experimental investigations. Technical details are summarized in [[18]-[20]].

The execution of the experiments with the specimens PL140 to PL144 was described in Hering et al. [[15]]. In these experiments, five different impactor velocities were used to 
generate severe damage grades in the test specimens. The range of speeds was between $44 \mathrm{~m} / \mathrm{s}$ and $74 \mathrm{~m} / \mathrm{s}$.

The experimental conditions for the tests on the strengthened $\mathrm{RC}$ plates corresponded to those described [[15]]: A four-point bearing located at the corners of the specimen was used for the plate. The distance between the centres of the supports along the edges of the specimen was $125 \mathrm{~cm}$. The supports contained load cells with which the support reaction was measured. The load cells are positioned under the corners of the plates, see Fig. 4. The labels of the load cells are LC. Furthermore, the deformation of the plates was measured at two points, positions w1 and L1: w1 was located on the upper side of the panel, L1 on the lower ones, see Fig. 3 and Fig. 4 . A flat, $380 \mathrm{~mm}\left(L_{\mathrm{Imp}}\right)$ long and $21.66 \mathrm{~kg}\left(m_{\mathrm{Imp}}\right)$ weighted steel impactor with a diameter of $100 \mathrm{~mm}\left(d_{\mathrm{Imp}}\right)$ was used for loading, see Table 1.

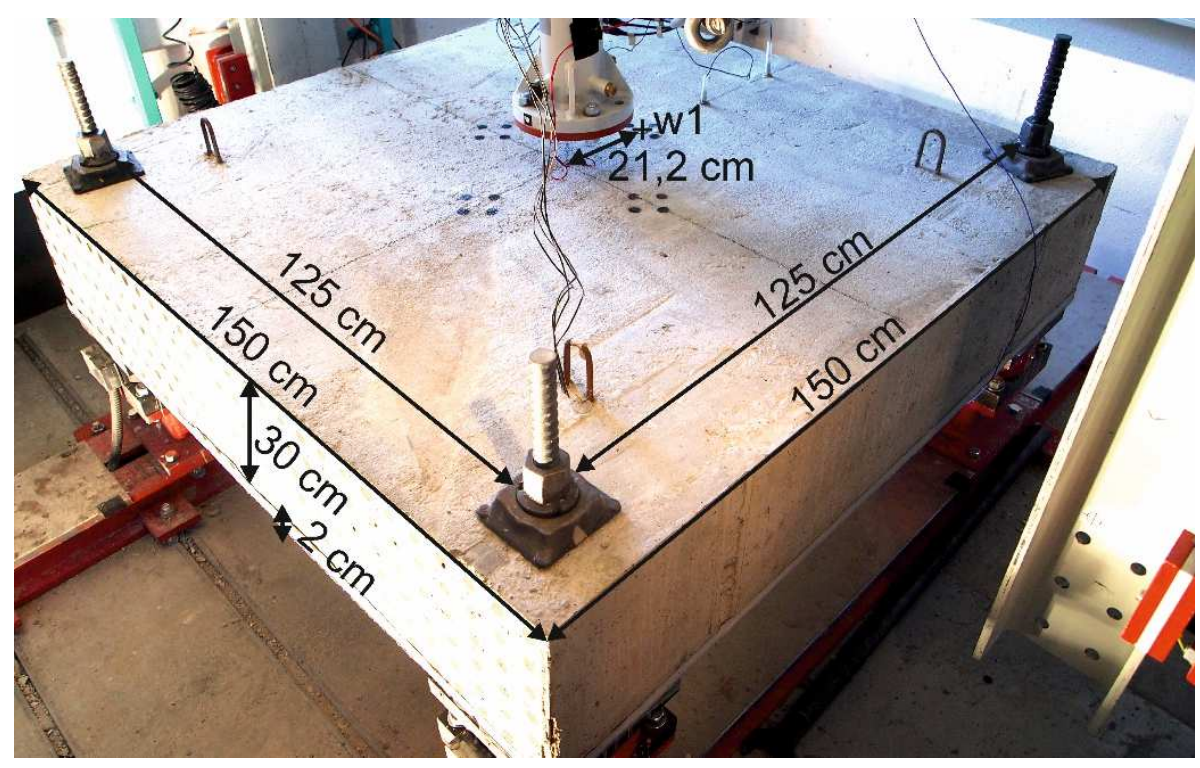

Fig. 3. View from above the specimen with dimensions, graphic by Hering.

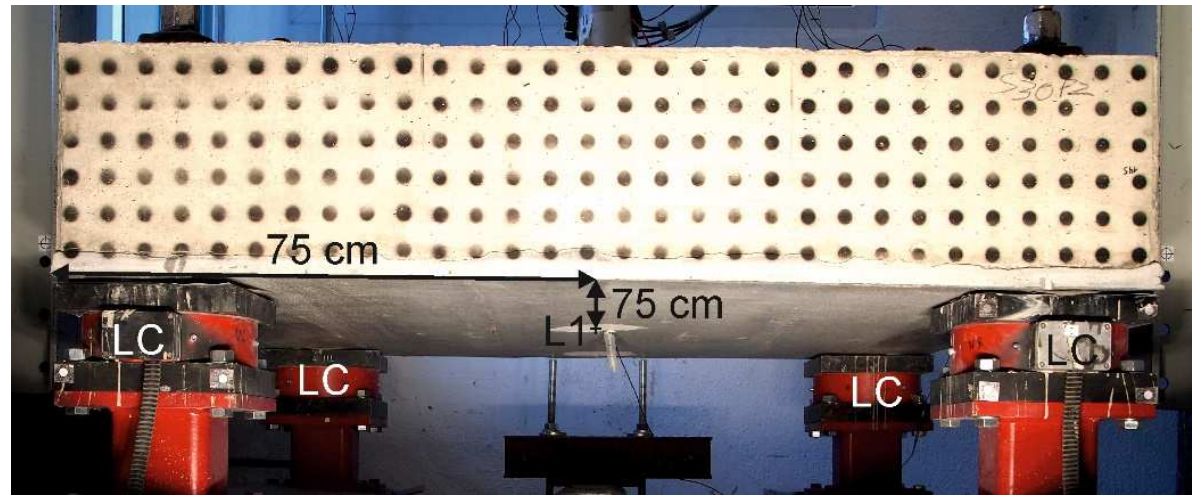

Fig. 4. View under the specimen with dimensions, graphic by Hering.

The choice of the impactor velocity for the experiments with the strengthened plates was based on the damage of the reference RC plates documented in [[15]]. Fig. 6 shows saw cuts through the reference RC plates on the left side. On the basis of the internal damage to the plates as shown in these sectional views, it was a matter of debate to use approx. $61 \mathrm{~m} / \mathrm{s}$ or 
approx. $68 \mathrm{~m} / \mathrm{s}$ as the impactor velocity. In both experiments a clear damage can be seen inside the plate. In the end, it was decided to use an impactor velocity of approx. $68 \mathrm{~m} / \mathrm{s}$. The decision in favour of the higher velocity is based on the need to ensure that the strengthening layer is activated. Therefore it seemed better to us to apply a little more impact velocity and thus more impact energy than too little. If there had been insufficient damage to the test specimen with the chosen configuration, the experiments would have had to be repeated. This had to be avoided.

\section{Exemplary experimental results}

As a result of the experimental investigation of the plates strengthened by different materials under impact load, three aspects are to be considered:

1. the support reaction measured by means of load cells;

2. the deflection of the plate; and

3. the saw cuts through the test specimens.

\subsection{Support reaction}

Frequently, the measured support reactions or support forces of impact experiments are given. However, it is difficult to draw specific conclusions about the load prevailing from these data because the measured reaction forces were determined from inertial forces of the test specimen and the load that really occurred. However, a separation of both forces has not yet succeeded satisfactorily and is still under research. These forces can, however, be used as comparative values within a series of similar tests and can be used to verify the functionality of the test setup. In our tests, for example, it is important that the impactor hits the centre of the plate in order to achieve similar behaviour in every quarter of the sample.

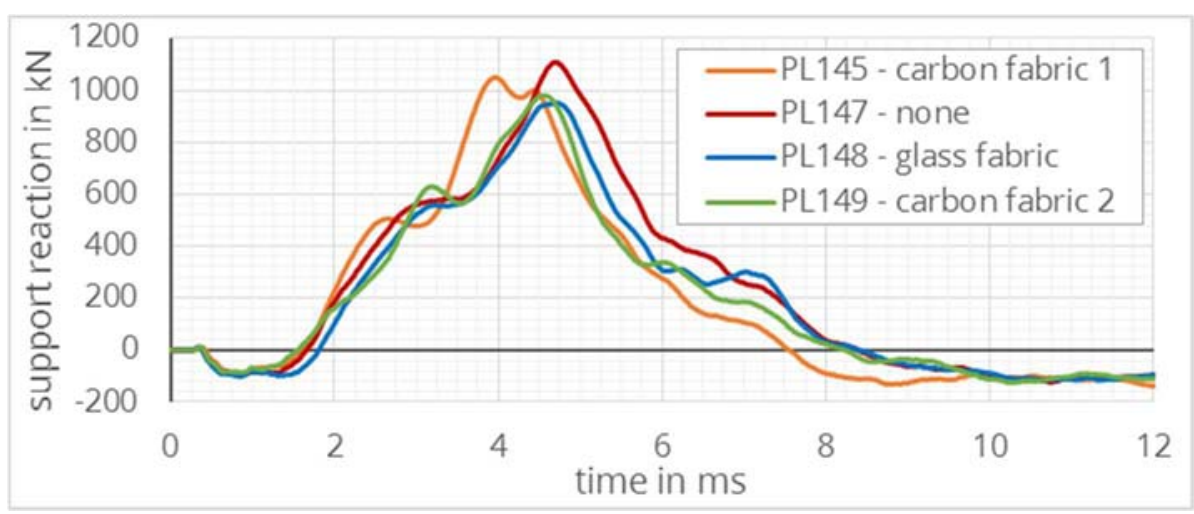

Fig. 5. Summarized reaction forces measured by the load cells, graphic by Hering.

Fig. 5 shows the support forces summed up from the four load cells. The support forces were recorded with a measuring rate of $200 \mathrm{kHz}$ and only slightly smoothed by means of a moving average filter, which approaches a low pass frequency of about $20 \mathrm{kHz}$, see [[15]]. For the curves shown in Fig. 5, only the reaction forces were added up. No further processing of the measured data or compensation of the inertial forces were performed. A direct comparison within the test program carried out with the strengthened plates seems plausible, because:

- all the plates had the same geometrical dimensions,

- the impactor velocity was the same for all experiments,

- the impactor used for the load was always the same. 
From this, it can be concluded that the occurring inertial forces must be nearly equal for all strengthened plates, and thus they are included to the same percentage in the measured reaction forces. Even if we do not know the exact value of the inertial forces, the data of the different tests are therefore comparable. The recorded similar curves show that the experiments are comparable. Both the duration of the first load increase and its amplitude fit well together in all four experiments.

A comparison with the measured support reaction of the non-strengthened RC plates was not carried out. Due to the subsequently applied $2 \mathrm{~cm}$ thick strengthening layer, the strengthened RC plates are heavier than the reference RC plates. For this reason, a direct comparison is not recommended, because the measured support reactions are influenced by the inertia of the test specimen.

\subsection{Sectional images}

After conducting the experiments, the test specimens were cut in the middle parallel to two long sides using a concrete saw, Fig. 6. As a consequence, a direct examination of the damage inside the specimen was possible. In the left half of the picture, the sectional images through the $30 \mathrm{~cm}$ thick reinforced concrete plates are displayed (taken from Hering et al. [[15]]). The impact velocities and specimen labels used in each case were supplemented in the picture. The sectional images were arranged so that the velocity of the impactor increases from top to bottom. On the right half, the sectional images of the subsequently strengthened plates are shown (partly taken from [[8]]).
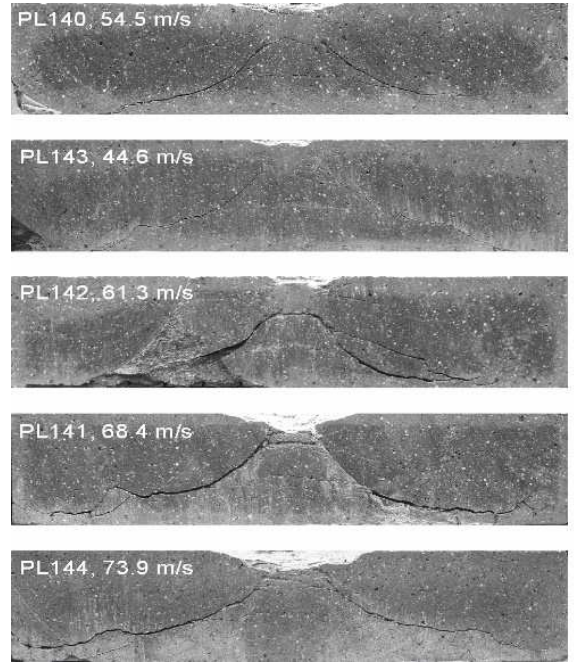
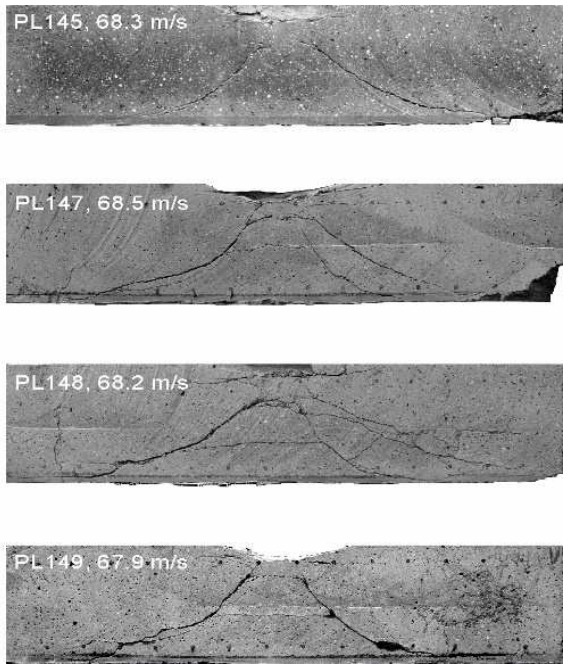

Fig. 6. Sectional images of the tested plates (30 cm thickness); PL140-144, see [[15]]; PL145 see [[8]];

PL147-149, graphic by Hering.

In Fig. 6, in the left half of the picture, one can clearly see how the damage inside the specimen increases with increasing speed [[15]] until the velocity of $68.4 \mathrm{~m} / \mathrm{s}$. From then on, the damage on the upper side of the test specimen also increases. If the sectional image of the subsequently strengthened RC plates are compared with these reference specimens, it can be determined that the damage pattern caused by the impact has the same characteristics for all specimens. The formation of a fracture structure is clearly visible in each case. This fracture body is separated from the rest of the test specimen by a crack. The crack begins on 
the upper side of the plate in the area hit by the impactor and runs at an increasingly decreasing angle to the lower side of the plate.

No separation of the strengthening layer and primary test specimen occurred with any subsequently strengthened plates. Furthermore, no spalling of the strengthening layer could be detected. Upon detailed examination (Fig. 7), it can be seen that the separation crack in test specimens PL145 (strengthened with fabric 1) is the least open compared to the other test specimens. Furthermore, an interesting characteristic in the crack path in the lower part of the plate can be found when looking at the test specimens PL147, PL148 and PL149. It can be seen here that the crack in sample PL147, whose strengthening layer was not reinforced, runs relatively straight through the strengthening layer. In contrast, the crack in samples PL148 (glass fabric) and PL149 (carbon fabric 2) propagates into the strengthening layer and then continues horizontally between the reinforcement layers of the strengthening layer.
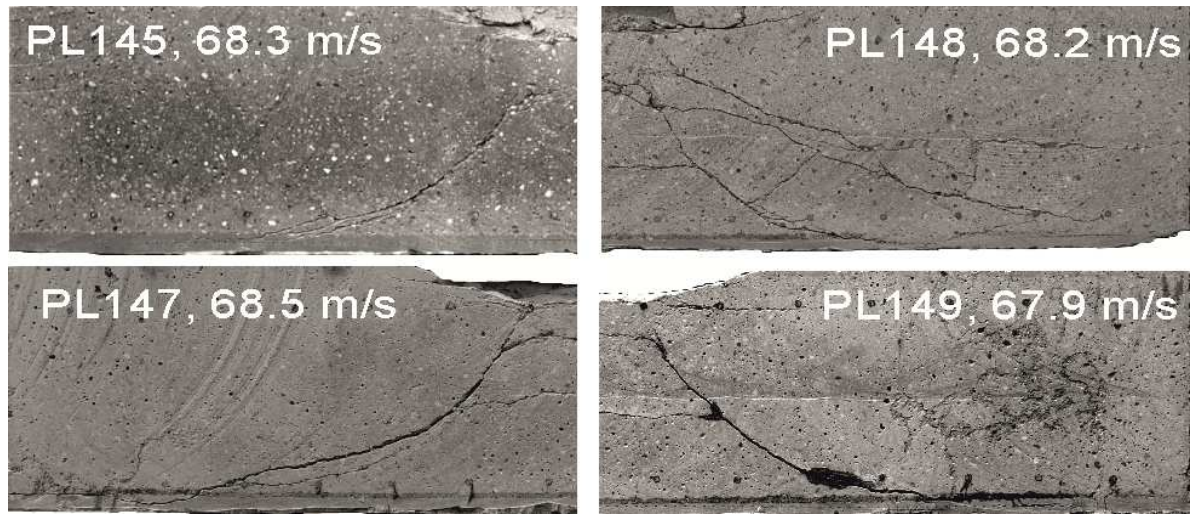

Fig. 7. Detailed view of the sectional images - strengthened plates, graphic by Hering.

\subsection{Deflection of the plates}

Fig. 8 shows the displacements measured on the upper side of the plates at position w1 (see Fig. 3). The deformation of the non-strengthened reference plate PL141 was also added. This figure clearly shows the effect of the strengthening layer on the deformation behaviour of the plates. The reference RC plate deforms much more under the applied load than the subsequently strengthened ones. Furthermore, it can be seen very clearly that the unreinforced strengthening layer (PL147) also has a clear influence on the deformation. This is, however, significantly less than in the case of the test specimens which were strengthened with reinforcement layers. A direct comparison of the fabrics used for the strengthening layer shows that carbon fabric 2 was able to minimize deformation the most.

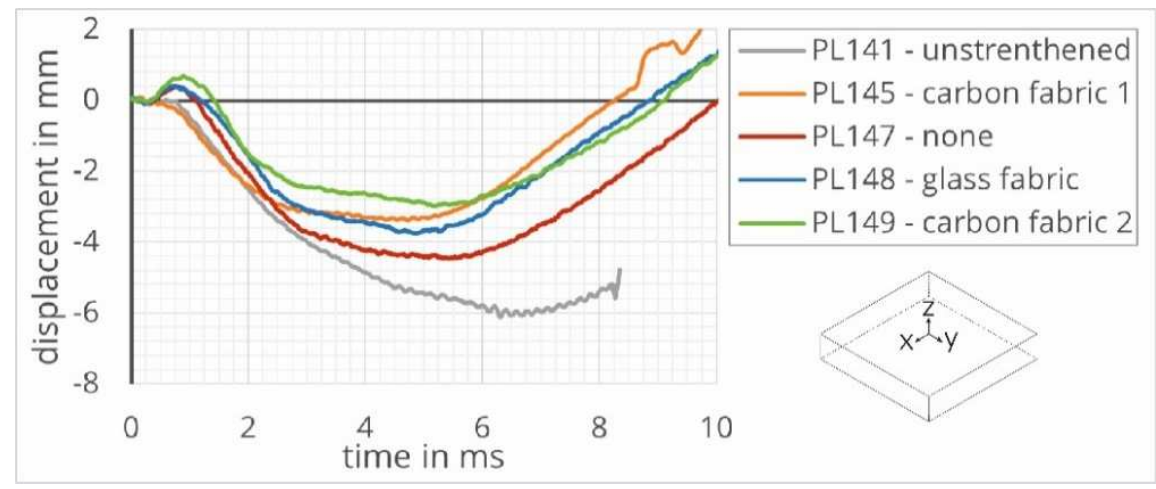


Fig. 8. Plate deformation measured at position w1 on the upper side of the plates near the impacted point, graphic by Hering.

Fig. 9 shows the deformations measured at position L1 in the plate's centre directly under the centre of the point of impact on the bottom side of the plate. As expected, the reference $\mathrm{RC}$ plate shows the greatest deformation. The deformations of the strengthened plates are smaller here. The same tendencies can be identified in Fig. 9.

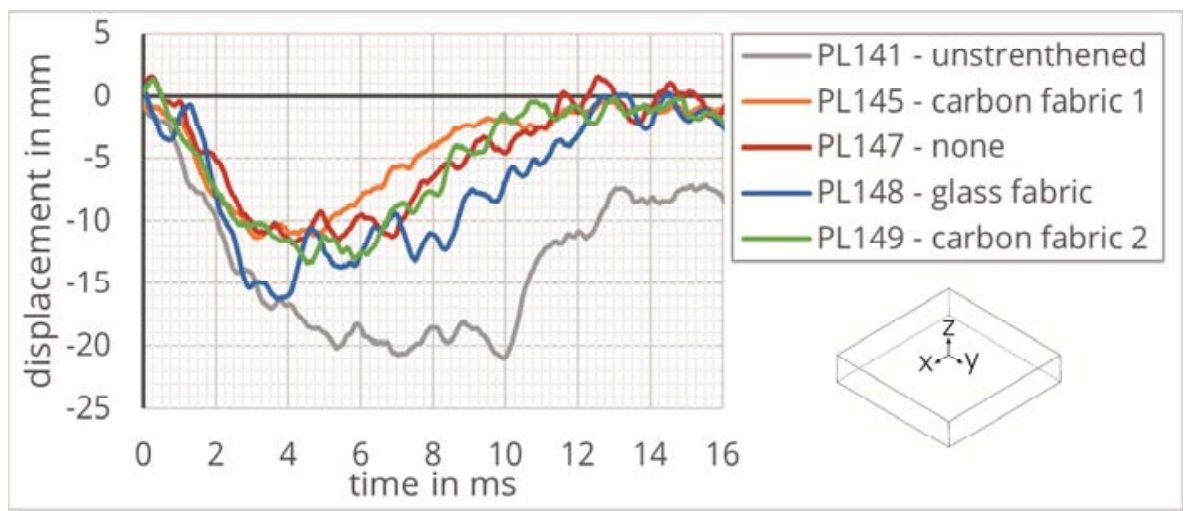

Fig. 9. Plate deformation measured centrically at the bottom of the plates (position L1), graphic by Hering.

\section{Conclusions}

In summary, it can be stated that the effect of the subsequently applied strengthening layer has almost no influence on the fracture behaviour inside the RC plates. An unreinforced strengthening layer could also produce good results, as the additional plate thickness has an effect on the deformation behaviour. Looking at the reinforcement materials in the strengthening layer, the carbon fabrics showed a slightly better performance in the global bending behaviour than the glass fabric.

The investigations presented here represent a part of the investigations carried out within the framework of the Research Training Group GRK 2250, funded by the Deutsche Forschungsgemeinschaft (German Research Foundation, DFG). Further investigations based on these results will be carried out in order to advance the systematic investigation of mineralbound strengthening layers.

Parts of the presented work (not strengthened plates) were funded by the German Federal Ministry of Economic Affairs and Energy (BMWi, project no. 1501541) on the basis of a decision by the German Bundestag.

Further thanks for support go to the research association 'Forschungskuratorium Textil e.V.'. 


\section{References}

[1] United States Army Corps of Engineers, Suppressive Shields Structural Design and Analysis Handbook (1977).

[2] P. Barr, Guidelines for the Design and Assestment of Concrete Structures subjected to Impact (United Kingdom Atomic Energy Authority, Warrington,1988).

[3] J. Eibl, K. Kreuser, Versuche zum Verhalten unterschiedlicher Stahlsorten in stoßbeanspruchten Platten (Deutschen Ausschusses für Stahlbeton - DAfStb - Verlag für Architektur und technische Wissenschaften, 1986).

[4] A. Saarenheimo, K. Calonius, M. Tuomala, Bending and punching studies on impact loaded Plate (In: Transactions of the 23rd Conference of Structural Mechanics in Reactor Technology (SMiRT 23). Manchster, United Kingdom : International Association for Structural Mechanics in Reactor Technology (IASMiRT), 10.-24. August 2015).

[5] C. Heckötter, J. Sierevs, Weiterentwicklung der Analysemethodik zur Berïcksichtigung komplexer Lastannahmen bei hochdynamischen Einwirkungen auf Stahlbetonstrukturen (Gesellschaft für Anlagen und Reaktorsicherheit - GRS, 2016).

[6] K. Schellenberg, On the Design of Rockfall Protection Galleries (ETH Zürich, Dissertation, 2009).

[7] I. Curosu, V. Mechtcherine, M. Hering, M. Curbach, Mineral-bonded Composites for Enhanced structural impact safety - Overview of the format, goals and achievements of the Research training Group GRK 2250 (Eds: G. Pijaudier-Cabot, P. Grassl, C. La Borderie, In: Proccedings of 10th International Conference on Fracture Mechanics of Concrete and Concrete Structures. Bayonne, Frankreich, 23.-26. June 2019).

[8] C. Cherif, Zierold, K., M. Curbach, M. Hering, Textilverstärkte Betonkonstruktionen für Impaktbeanspruchungen (final report : IGF 19009 BG, Dresden, 2019).

[9] A. Peled, B. Mobasher, A. Bentur, Textile Reinforced Concrete (CRC Press, 2017).

[10] L. N. Koutas, Z. Tetta, D. A. Bournas, T. C. Triantafillou, Strengthening of Concrete Structures with Textile Reinforced Mortars: State-of-the-Art Review. J. Compos. Constr. 23, (2019).

[11] C. Carloni, D. A. Bournas, F. G. Carozzi, T. D’Antino, G. Fava, F. Focacci, G. Giacomin, G. Mantegazza, C. Pellegrino, C. Perinelli, C. et al., Fiber Reinforced Composites with Cementitious (Inorganic) Matrix. In: Design Procedures for the Use of Composites in Strengthening of Reinforced Concrete Structures - State-of-the-Art Report of the RILEM Technical Committee 234-DUC 2016; Pellegrino, C., Sena-Cruz, J., Eds.; Springer: Dordrecht, The Netherlands, 2016; Chapter 9; pp. 349-39.

[12] A. Schumann, S. May, M. Curbach, Experimental Study on Flexural Strengthening of Reinforced Concrete Structures with Carbon Reinforced Concrete (Eds: W. Derkowski, P. Gwozdziewicz, L. Hojdys, P. Krajewski, M. Pantak, In: Proc. of the fib Symp. 27.-29.5.2019 in Krakau, Poland, 2019).

[13] S. Scheerer, R. Zobel, E. Müller, T. Senckpiel-Peters, A. Schmidt, M. Curbach, Flexural Strengthening of RC Structures with TRC-Experimental Observations, Design Approach and Application. Appl. Sci. 9, 1322 (2019).

[14] S. May, A. Schumann, S. Bergmann, M. Curbach, J. Hegger, Shear Strengthening of Reinforced Structures with Carbon Reinforced Concrete (Eds: W. Derkowski, P. Gwozdziewicz, L. Hojdys, P. Krajewski, M. Pantak, In: Proc. of the fib Symp. 27.29.5.2019 in Krakau, Poland, 2019).

[15] M. Hering, T. Kühn, F. Bracklow, M. Curbach, Impact experiments with reinforced concrete plates of different thicknesses, Struct. Concr. (2019). 
[16] DIN Deutsches Institut für Normung e.V. (August 2009). DIN 488-1 Reinforcing steels - Part 1: Grades, properties, marking.

[17]PAGEL, PAGEL TUDALIT-FEINBETON ${ }^{\circledR}-$ Technical data sheet 0606 (http://www.pagel.com/all/pdf/gb/tf10_gb.pdf, Germany, 2019).

[18] https://tu-dresden.de/bu/bauingenieurwesen/imb/labor/ausstattung/falltum; Retrieved 14.10.2019

[19] M. Just, M. Curbach, T. Kühn, M. Hering, Bauteilverhalten unter stoßartiger Beanspruchung durch aufprallende Behälter (Flugzeugtanks) - Phase 1A: Maßstabseffekte bei stoßartiger Beanspruchung. Report of GRS research project no. 1501438 (IMB TU Dresden, Germany, 2016), DOI: 10.2314/GBV:868615218.

[20] M. Hering, T. Kühn, M. Curbach, Bauteilverhalten unter stoßartiger Beanspruchung durch aufprallende Behälter (Flugzeugtanks) - Phase 1B: Quantifizierung der Schädigungen des Betongefüges, Teilprojekt: Fallturmversuche. Report of GRS research project no. 1501479 (IMB TU Dresden, Germany, 2017), DOI: 10.2314/GBV:100128142X. 